\title{
A PARASITOLOGICAL AND SEROLOGICAL MALARIA SURVEY IN AMAZONAS, 1971
}

\author{
C. C. Draper *, P. D. Marsten, *, Aluizio Prata **, Heitor Vieira Dourado *** \\ and $\mathbf{J}$. C. Bina $* * * *$
}

Thick blood films and malaria indirect fluorescent antibody test (P. Ialciparum and $\mathbf{P}$. vivax) were done in four different regions in Amazonas. There was a very low prevalence of parasites and the antibody rates suggest a small amount of transmission and that $\mathrm{P}$. vivax was the predominant parasite. The calculation of probability of being infected per year was about $8 \%$ in Tefé. Coari, Colonia Fernando Costa and Labrea and $0.8 \%$ in Anori.

Malaria due to Plasmodium falciparum aud $P$. vivax, was formerly hyperendemic in Amazonas. In 1967-1968 the spraying of houses with the residual insecticide DDT, on a regular cycle, was started and this has been very effective against the main vector, Anopheles darlingi, which has almost disappeared from houses. There has also been widespread distribution of antimalaria drugs. This resulted in a dramatic decrease in the incidence of malaria in man although passive surveillance figures for 1970 still showed a parasite index of from 0.3 to $15 \%$ in different municipalities of this vast area.

In July-August 1971 a survey for malaria antibodies was done in four different regions in order to compare serological and parasitological data, and to see whether the former could give further information about the amount of malaria transmission which might still be occurring.

\section{METHODS}

Drops of blood were collected on pieces of Whatman No. 3 chromatography papel, 5 sets of drops from different individuals being collected on one piece of paper measuring about $14 \times 9 \mathrm{cms}-$ a convenient size to handle. When fully dried these were sealed into polythene bags and protected from extremes of heat before being tested. In the laboratory a disc, or discs, of paper equivalent to $50 \mu 1$. of blood was cut out and eluted in $0.4 \mathrm{ml}$. of phosphate buffered saline (PES) to give an approximate $1 / 16$ dilution of serum and this, and subsequent dilutions of positive sera made by the 'Microtitre' method, were used to test for antibodies in the malaria indirect fluorescent antibody test (IFAT). The latter was done with thick blood films of Plasmodium falciparum and $P$. vivax by the method of Sulzer et al. in 1969, (3) as

* London School of Hyglene and Tropical Medicine.

** University of Brasilia.

*** University of Amazonas.

**** Fundação Gonçalo Moniz, Salvador Submitted to publication on 5.2.1973. 


\section{TABLE}

MALARIA PARASITES AND ANTIBODIES. AMAZONAS, 1971: AREAS A, B, C AND D

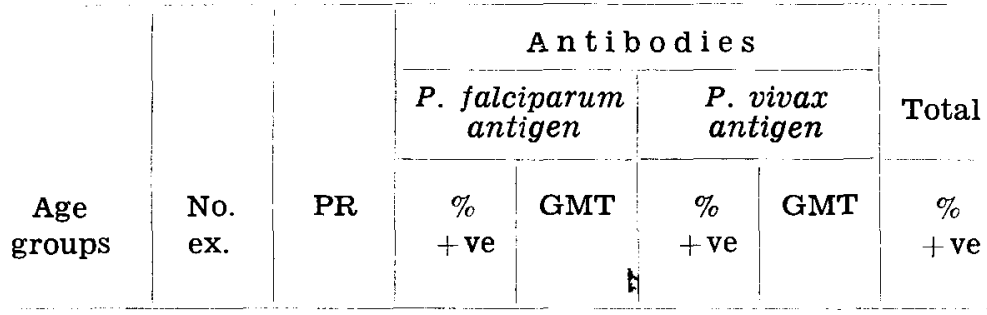

AREA A

\begin{tabular}{rl|c|c|c|c|c|c|c|}
\hline $0-11$ & $\operatorname{mos}$ & 10 & 0 & 20 & 5.0 & 30 & 5.3 & 30 \\
$12-23$ & $\operatorname{mos}$ & 10 & 0 & 10 & 4.0 & 10 & 6.0 & 10 \\
$2-4$ & yrs & 29 & 3 & 0 & 0 & 17 & 6.4 & 17 \\
$5-9$ & yrs & 69 & 0 & 25 & 5.2 & 57 & 5.8 & 58 \\
$10-14$ & yrs & 51 & 0 & 47 & 5.3 & 61 & 6.4 & 63 \\
$15-19$ & yrs & 15 & 0 & 53 & 6.5 & 53 & 7.0 & 60 \\
Over 20 yrs & 108 & 0 & 77 & 6.9 & 84 & 7.4 & 84
\end{tabular}

AREA B

\begin{tabular}{rl|r|r|r|r|r|r|r}
\hline $0-11$ & mos & 7 & 0 & 0 & 0 & 0 & 0 & 0 \\
$12-23$ & mos & 4 & 0 & 0 & 0 & 0 & 0 & 0 \\
$2-4$ & yrs & 25 & 0 & 0 & 0 & 0 & 0 & 0 \\
$5-9$ & yrs & 49 & 0 & 0 & 0 & 8 & 4.5 & 8 \\
$10-14$ & yrs & 21 & 0 & 0 & 0 & 10 & 5.0 & 10 \\
$15-19$ & yrs & 8 & 0 & 0 & 0 & 0 & 0 & 0 \\
\hline Over 20 yrs & 34 & 0 & 18 & 5.8 & 24 & 6.0 & 26
\end{tabular}

AREA C

\begin{tabular}{cl|r|l|l|l|l|r|r}
\hline $0-11$ & mos & 2 & 0 & 0 & 0 & 0 & 0 & 0 \\
$12-23$ & mos & 5 & 0 & 0 & 0 & 40 & 6.0 & 40 \\
$2-4$ & yrs & 17 & 6 & 18 & 8.3 & 24 & 7.0 & 24 \\
$5-9$ & yrs & 47 & 2 & 19 & 6.3 & 30 & 6.4 & 30 \\
$10-14$ & yrs & 56 & 0 & 37 & 5.6 & 64 & 6.3 & 68 \\
$15-19$ & yrs & 27 & 0 & 67 & 5.8 & 89 & 6.2 & 89 \\
Over 20 yrs & 38 & 0 & 58 & 6.8 & 82 & 7.5 & 84
\end{tabular}

AREA D

\begin{tabular}{rl|r|r|r|r|r|r|r}
$0-11$ & $\operatorname{mos}$ & 5 & 0 & 20 & 4.0 & 20 & 4.0 & 20 \\
$12-23$ & $\operatorname{mos}$ & 15 & 0 & 0 & 0 & 13 & 4.0 & 13 \\
$2-4$ & yrs & 55 & 0 & 7 & 7.0 & 29 & 5.4 & 29 \\
$5-9$ & yrs & 75 & 0 & 17 & 5.5 & 49 & 5.2 & 49 \\
$10-14$ & yrs & 64 & 1 & 23 & 5.2 & 61 & 5.4 & 62 \\
$15-19$ & yrs & 35 & 0 & 43 & 6.4 & 69 & 6.7 & 69 \\
Over 20 yrs & 41 & 0 & 80 & 7.4 & 88 & 7.4 & 88
\end{tabular}

$\mathrm{PR}=$ parasite rate. $\mathrm{GMT}=\log _{2}$ of the geometric mean reciprocal titre of positives only. 
modified by Bruce-Chwatt et al. (1). For the detection of parasites thick blood films were stained with Giemsa and about 100 microscope fields were examined before declaring a film negative.

\section{RESULTS}

The following areas were surveyed: Tefé and Coari (Area A) on the Solimões, which have been taken together as they had similar data; Anori (Area B), also on the Solimōes but which has been considered separately as the data were different from the former; Colcnia Fernando Costa and nearby villages (area $C$ ) in Roraima; Lábrea (Area D) on the Purus.

The results of the blood film examinations and the IFATs are given in the Table and Figure. In the latter the total antibody prevalence rates by age groups are plotted on a reverse log scale. Lines corresponding to the figures for the annual probability of being infected per year (R), which give the best fit for the observed data, have been drawn in, as described by Draper et al. (2). For the calculation of $R$ the two youngest age groups have been ignored, as they often possess congenital antibodies derived from immune parents, and only the next three age groups, up to 14 years, have been used as we are particulary interested in recent malaria infections.

As can be seen, although there was a very low prevalence of parasites in all areas, the antibody rates suggest that a small amount of transmission has in fact been occurring recently. In Areas A, C and $\mathrm{D}$ this was equivalent to about an $8 \%$ probability of being infected per year. In Area $B$, in which by contrast even the adult antibody rates are very low, showing that there has never been much transmission there, the probability of being infected was about $0.8 \%$ per year. The geometric means titres (GMTs) are consistent with the occurrence of recent infection. The higher antibody rates with the $P$. $v i$ vax antigen than with the $P$. falciparum antigen, and the higher GMTs of the antibodies, suggest that $P$. vivax was the predominant parasite.

\section{DISCUSSION}

Because they represent the total past experience and persist for many years in most cases, unless there is prompt radical antimalaria treatment, antibody rates give a more accurate measure of malaria transmission than parasite rates. The presence of parasites in infected people is usually intermittent and they may well be depressed to submicroscopic levels by even small doses of antimalaria drugs, which would not affect development of antibodies. The measurement of antibody rates are potentially most valuable at the lower levels of transmission as here. The differences in the residual amount of transmission found are proportional to the passive surveillance figures for 1970 (SUCAM reports): for Areas $\mathbf{A}, \mathbf{C}$ and $\mathbf{D}$ the percentages of positive slides found then were from 1.3 to $15 \%$, while for Area B it was nil.

\section{ACKNOWLEDGEMENTS}

We owe many thanks to Dr. Agostinho Cruz Marques for providing all facilities and for much assistance in doing the survey.

Os autores fizeram pesquisa de hematozoário e reação de imuno-fluorescência indireta (P. vivax e P. falciparum) em 922 pessoas vivendo em Tefé, Coari, Anori, Colônia Fernando Costa (Roraima) e Lábrea. Verificaram que a transmissâo da malária era baixa e que havia predominância do P. vivax. Calcularam que a probabilidade de se infectar em um ano era de $8 \%$ em Tefé, Coari, Colônia Fernando Costa e Lábrea e de 0,8\% em Anori. 
MALARIA ANTIBODIES (RESULTS WITH 2 ANTIGENS COMBINED) AND PROBABILITY OF BEING INFECTED/YEAR (R)

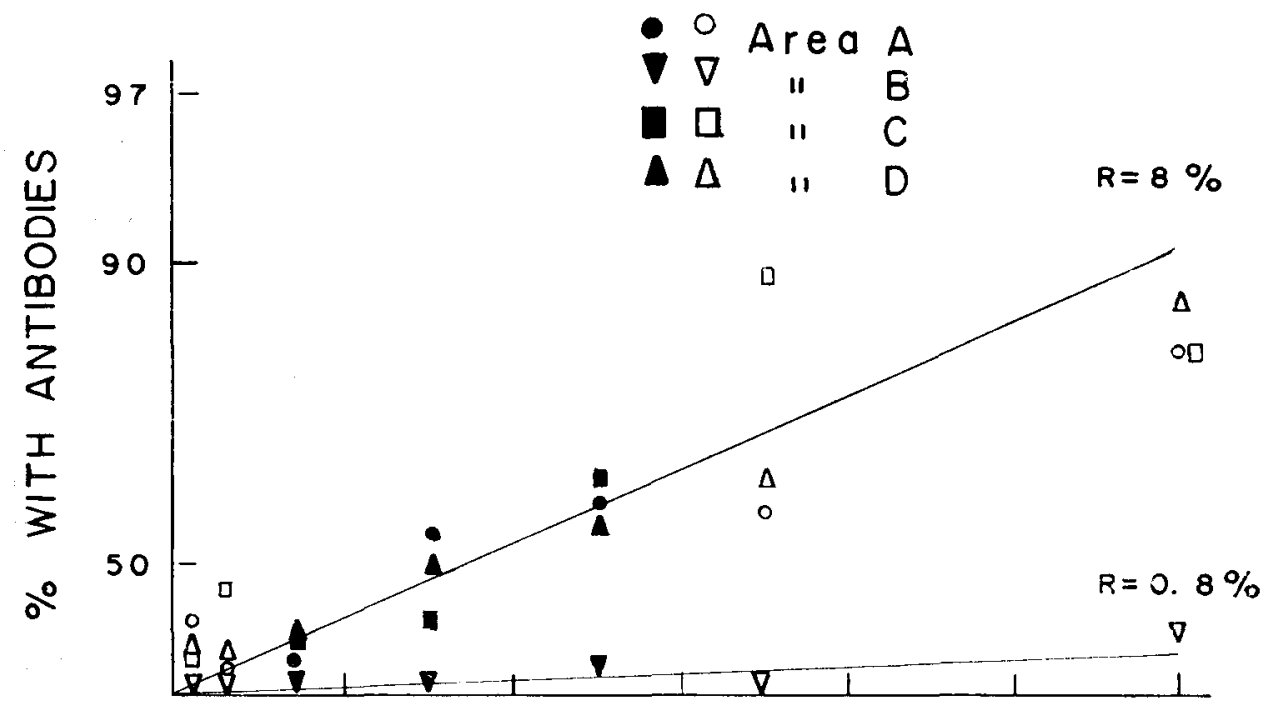

GEOMETRIC MEAN TITRES OF MALARIA ANTIBODIES WITH 2 ANTIGENS,

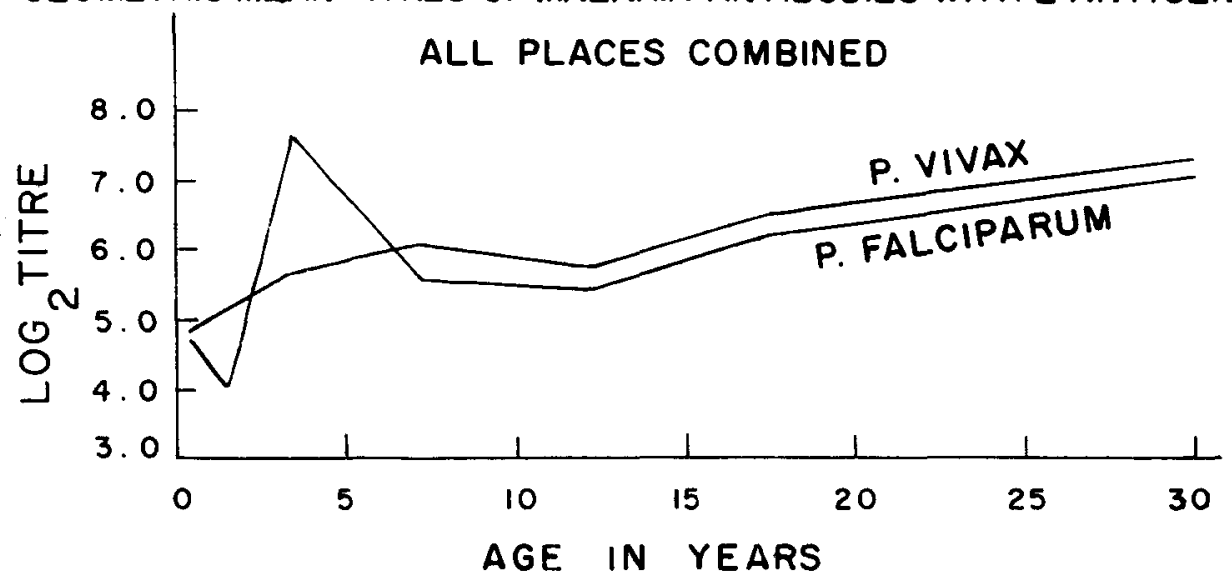




\section{REFERENCES}

BRUCE-CHWATT, L. J., DODGE, J. S., DRAPER, C. C., TOPLEY, E. and VOLLER, A. - Sero-epidemiological studies on population groups previously esposed to malaria. Lancet, $i, 512-514,1972$.

DRAPER, C. C., VOLLER, A. and CARPENTER, R. G. - Amer. J. trop. Med. Hyg., (in press), 1972.
SULZER, A. J., WILSON, M. and HALL, E. C. - Indirect fluorescent-antibody tests for parasitic diseases. V. An evaluation of a thicksmear antigen in the IFA test for malaria antibodies. Amer. J. trop. Med. Hyg., 18: 199-205, 1969. 